\title{
I 2. Into the Centre of Things: Poetic Travel Narratives in the Work of Kathleen Jamie and Nan Shepherd
}

\author{
Eleanor Bell
}

Here then may be lived a life of the senses so pure, so untouched by any mode of apprehension but their own, that the body may be said to think. Each sense heightened to its most exquisite awareness, is in itself total experience. (The Living Mountain 82)

These reflections on walking in the Cairngorms are from Nan Shepherd's The Living Mountain, written in the I940s. For Shepherd, the 'total experience' offered by the mountains opened up deeper channels of the self, during which, she writes, 'I am not out of myself, but in myself. I am'. ${ }^{1}$ Previous critics have picked up on the meditative qualities within Shepherd's work, where the mountains always remain magical and ultimately impenetrable in her Zen-like reflections: 'The journey is itself part of the technique by which the god is sought. It is a journey into Being; for as I penetrate more deeply into the mountain's life, I penetrate also into my own.' (84) While critics such as Robert Macfarlane have recently acknowledged Nan Shepherd's significant contribution to mountain literature, bringing this previously neglected work into prominence, this essay will reflect on some of the possible reasons why The Living Mountain lay unpublished for three decades, until it was eventually published by Aberdeen University Press in 1977. In doing so, specific connections will be made between Nan Shepherd and Kathleen Jamie, both explorers and poets whose texts, although produced over half a century apart, are similar in their blurring of the boundaries between travel and nature writing. Yet while open to the spiritual dimensions of travel writing, Jamie has also been realistic and critical of the genre, acknowledging, for example, its often-inherent masculine bias and negative environmental impacts. In comparing Shepherd's The Living Mountain with some of Jamie's essays in Findings and Sightlines, which focus on travel and nature, this essay will examine the social and cultural context of each writer's quest, illuminating in turn some of their own particular 'findings'.

Before discussing The Living Mountain, however, it is worth reflecting on the 
context of Scottish travel writing preceding Shepherd's earlier in the twentieth century. When Edwin Muir set off on his famous Scottish Journey in I 934 in a I92 I Standard car gifted from the artist Stanley Cursiter, for example, his intention was to provide 'a record of a journey' and, he continued,

to give my impressions of contemporary Scotland; not the romantic Scotland of the past, nor the Scotland of the tourist, but the Scotland which presents itself to one who is not looking for anything in particular, and is willing to believe what his eyes and ears tell him.'2

Muir's Scottish Journey provides an interesting snapshot of Scotland at the time, especially in terms of the binary oppositions it constructs between the rural and the urban (its depictions of Glasgow are particularly haunting), and in terms of its politics of place. Yet Muir's text was not the first of its kind; there were several other important travelogues and investigations of nation prior to Muir's Scottish Journey that could be mentioned here: H. V. Morton's In Search of Scotland (I929), Harry Batsford and Charles Fry's The Face of Scotland ( 1933), followed by George Blake's The Heart of Scotland (I934), which then became the source of documentary films for John Grierson (The Face of Scotland (I938) and The Heart of Scotland (I96I)). Another important text at the time was Hugh MacDiarmid and James Leslie Mitchell's (Lewis Grassic Gibbon's) Scottish Scene: or The Intelligent Man's Guide to Albyn (I934), comprising a series of essays, stories and poems written alternately by Mitchell and MacDiarmid, again attempting to take the literary and cultural pulse of the country at the time.

While all of the texts mentioned above share this similar 'intelligent man's' desire to document place, recording aspects of lived experience as a means of capturing elements of Scotland in transition, Shepherd's travelogue is far more modest by comparison. Illuminating an urge for solitary exploration and deep reflection, her text has no ambition to be authoritative or age-defining. Rather, throughout Shepherd's text is the impulse to absolve the self of ego, to give precedence to the power of nature in order to fully experience Being. As critics such as Margery Palmer McCulloch have pointed out, many of the women associated with the Scottish literary revival era were similarly motivated by the search for self-determination at personal rather than national levels. ${ }^{3}$ While Shepherd was in correspondence with many writers at the heart of the Scottish Renaissance movement, clearly familiar with its objectives, she nonetheless chose to produce a text in which 'journeying out' is a means of 'journeying in'; the focus is on interiority, the sensory awareness and limitlessness of the self offered in the face of the sublimity of the mountains.

Another crucial reason for the neglect of Shepherd's text relates to its moment of historical production. While the I930s saw a burgeoning interest in and fascination with travel in the Scottish, and more widely British contexts, by the time Shepherd produced her text towards the end of World War Two the culture had clearly shifted away from such concerns. ${ }^{4}$ Shepherd commented that 'the only person who read the manuscript then was Neil Gunn, and that he should like it was not strange, because 
our minds met in just such experience as I was trying to describe. ${ }^{5}$ Although Gunn was a firm supporter of her work ('he made a couple of suggestions as to publication, but added that in the circumstances of the time a publisher would be hard to find'), she continues:

I wrote one letter at his instigation and received a courteous and negative reply and the manuscript went into a drawer and has lain there ever since.

Now, an old woman, I begin tidying out my possessions, and, reading it again, I realize that the tale of my traffic with a mountain is as valid today as it was then. That it was a traffic of love is sufficiently clear; but love pursued with fervour is one of the roads to knowledge. ${ }^{6}$

The Living Mountain contains many passages where this 'traffic of love' is evidently clear. In her preface to the 1977 edition Shepherd makes a sharp contrast between 'man' and 'mountain', between the natural landscape and the lived space into which it is transformed:

Aviemore erupts and goes on erupting.

Bulldozers birze their way into the hill.

Roads are made, and re-made, where there were never roads before.

Skiers, swift, elate, controlled, miracles of grace and

Precision, swoop and soar - or flounder - but all with exhilaration ... ${ }^{7}$

The man-made often jars with nature, yet the natural world is of a higher order, where human endeavours can only be understood as transient by comparison. For the attuned observer such as Shepherd, the immensity of the natural world readily usurps the marks made by mankind. Shepherd writes: 'all these are matters that involve man. But behind them is the mountain itself, its substance, its strength, its structure, its weathers. It is fundamental to all that man does to it or on it.' (iv) To look upon this juxtaposition of nature and the man-made is all part of a wider need to see beyond the commonplace, to reach for some form of connection with higher being: 'so, simply to look on anything, such as a mountain, with the love that penetrates to its essence, is to widen the domain of being in the vastness of non-being. Man has no other reason for his existence.' (79-80)

Commenting on The Living Mountain in his own poetic travel narrative, Beside the Loch of the Green Corrie, Andrew Greig observes that:

Hard to believe it was written in the Forties; it anticipates by sixty years aspects of the 'Nature writing' of our time. The product of years of stravaiging around in the Cairngorms, [The Living Mountain] understands and conveys better than anyone the absolute physicality, the immanence of the transcendence that abruptly swoops and plucks you in its hooked talons out of the ordinary and carries you not away from this world but into the beating, unsayable heart of it 
... She was a wonderful noticer, the kind of noticing that opens a crack into the centre of things. ${ }^{8}$

Given Shepherd's anticipation of the concerns of contemporary nature writing, it is not surprising that Robert Macfarlane, a key writer at the heart of this movement, provided the introduction for the reissue of The Living Mountain published by Canongate in 20I I. Having first read Shepherd's text in 2003, Macfarlane, drawing on connections with Merleau-Ponty's theories of embodiment, goes on to explain the reasons why he continues to be humbled by the radical nature of her text:

Radical, because Shepherd was a woman writing out of a Highland Scottish culture in which the cherishing of the body was not easily discussed. And radical because, as philosophy, it was cutting-edge. In the same years that Shepherd composed The Living Mountain, the French philosopher Maurice Merleau-Ponty developed his influential theory of the body-subject. [. . . His work, particularly The Phenomenology of Perception (I945), was dedicated to enriching the idea of the body, such that it could be said both to perceive and to think. Merleau-Ponty described this embodied experience as 'knowledge in the hands', a phrase that could have come straight from Shepherd. 'The body is not ... negligible,' she wrote, 'but paramount'. ${ }^{9}$

In many ways Shepherd's text defies simple categorisation. On the surface it is an attempt to explore the Cairngorms, to document the experience of walking in the mountains, but it is more deeply concerned with the sense of transcendence offered to those who are attuned; travel writing, nature writing, philosophical quest - all three are inherently interconnected in The Living Mountain. The raison d'être of Shepherd's text, it seems, is to articulate the moment of connection between mind, body and environment: her 'traffic of love' in the Cairngorms as a quest for connection with nature in the most authentic possible sense, especially given the fraught ways in which the man-made world continues to impinge on nature.

While for Shepherd 'journeying out' could be described as a spiritual and largely timeless quest (with the exception of a few incidental man-made interruptions), in Jamie's writings, by contrast, the trappings of the twenty-first century are all too present. Tensions between writing, motherhood and the need to juggle many aspects of a busy life are simultaneously set against the need to probe beneath the surface of the everyday in order to illuminate small moments of lived experience and aspects of the natural environment more thoroughly. In doing so, in Jamie's work it is not uncommon for the profound to interconnect with the mundane, for the poetic to be interspersed with the domestic. In this sense Jamie writes from a personal space which sees the value of recording the everyday within a grander order. It is perhaps these very human qualities of her essays on travel and nature, though - seeing the domestic within the wild, and vice versa - which are central to their appeal. Thus it is not unusual for moments of potential transcendence in her work to come down to earth with a realist bump. ${ }^{10}$

In her essay 'Darkness and Light' in Findings, for example, where she aspires to 
experience darkness in its most natural forms ('I'd a notion to sail by night, to enter into the dark for the love of its textures and wild intimacy'), Jamie attempts to visit Maes Howe, the Neolithic burial chamber in Orkney, during the winter solstice $\left(F_{3}\right)$. The irony of finding the authentic in such an oft-visited place is not lost on Jamie: 'In its long, long existence it has been more forgotten about than known, but in our era it is open to the public, with tickets and guides and explanatory booklets' (F I o). Despite Jamie's best attempts to experience Maes Howe in isolation, she ends up being escorted by a Historic Scotland guide, only to be informed that there are also surveyors, with light-emitting equipment, working on site:

Inside was bright as a tube train, and the effect was brutal. I'd expected not utter darkness, but perhaps a wombish-red. Rob was carrying a torch but this light revealed every crack, every joint and fissure in the ancient stonework. At once a man's voice said, 'Sorry, I'll switch it off,' but the moment was lost and, anyway, I'd been forewarned ... We entered the tomb and, in that fierce white light, it was like that moment which can occur in midlife, when you look at your mother and realise with a shock that she is old. (F I 4 )

The sharp contrasts between light and dark in this essay can also be read as juxtapositions between culture and nature, the sense that 'nature' cannot be apprehended in isolation; nature is perhaps most meaningful when mediated through personal experience, and often in Jamie's works this takes a domestic turn. Reflecting on her first, technologically illuminated experience of Maes Howe, and a subsequent return trip, this time with only the Historic Scotland guide, Jamie stops to do some Christmas shopping in Stromness:

I wandered into a toy shop, all bright and lit for Christmas, and in there picked up a silver plastic tiara. My little daughter [.. .] would love this. Standing there in the bright shop with this ridiculous tiara in my hand, turning it so it sparkled, I was thinking about light. I suppose I'd been hoping for a trick of the light at Maes Howe. No, trick was the wrong word. The tomb-builders had constructed their cairn to admit a single beam of solstice light: it was the bending of a natural phenomenon to a human end, somewhere between technology and art. But not art either: drama. [. . .] A very ancient drama, going right back to the Neolithic. Were they the first people, I wondered, to articulate this metaphor of light and dark, of life and death [. . .]

Then the shop-keeper said, 'Enjoy it while it lasts.'

'I'm sorry?'

She nodded toward the plastic tiara in my hand.

'My little girl used to love these things, all glittery and bright. But she's fourteen now, and wears nothing but black.' (F 22-3)

Here, an ironic association between the Neolithic drama of light and dark, life and death, is to be read alongside a contemporary drama of light and dark: the plastic tiara shimmering in a toy shop, symbolic of childhood innocence set against ado- 
lescent darkness. Such contemporary, seemingly superficial comparative backdrops, therefore, allow Jamie access to hidden recesses, deeper levels of comparison. Jamie may feel compelled to incorporate elements of lived family life into her reflections as this is what comes naturally to her, yet as readers we see that often the most perceptive examinations of nature are found in the most unexpected places, that our very understanding of what nature is, is often best mediated through the seemingly trivial or commonplace.

The 2008 Granta issue The New Nature Writing contains writing by, among others, Kathleen Jamie, Richard Mabey, Jonathan Raban and Robert Macfarlane. In his editorial introduction, Jason Cowley suggests that 'the best new nature writing is also an experiment in forms: the field report, the essay, the memoir, the travelogue', and, he goes on, 'if travel writing can often seem like a debased and exhausted genre, nature writing is its opposite: something urgent, vital and alert to the defining particulars of our times'. ${ }^{11}$ Cowley goes on to explain that the writers in this particular edition are all 'on a journey of discovery, as the best travel writers were'; the 'new nature writing' is 'about new ways of seeing'. ${ }^{12}$ Often these investigative reflections are at a local level, for, as Tim Dee writes, 'the more a globalised future awaits, the sweeter the local patch seems.' ${ }^{, 13}$

Both Findings (2005) and Sightlines (2012) reveal a narrative voice that, while always questioning and open to poetic discovery, is nonetheless confident and assured. Building on The Golden Peak: Travels in Northern Pakistan (1993), in which the young poet travels solo in the Northern mountains, Jamie's two most recent collections are simultaneously rooted in Scotland, yet keen to discover it anew through journeys into the self and nature. As with Shepherd's focus on the body as site of mediation for nature, Jamie's investigations are likewise often either mediated through the body or indeed use the body as the source of investigation itself, as is the case in her Sightlines essay 'Pathologies' (which also appeared in the 2008 Granta 'New Nature Writing' issue). In this essay, Jamie explains that after attending a conference on nature, where she had come home 'grumpy', thinking 'it's not all primroses and otters', she was compelled to get in touch with an acquaintance, a clinical consultant pathologist, at Ninewells Hospital in Dundee, as a means of exploring 'inner nature'. Jamie writes: 'there's our own, intimate, inner natural world, the body's weird shapes and forms, and sometimes they go awry' ( $\left.S_{24}\right)$. With consent from the pathologist, Jamie observes some of his work, during which one of the examinations is of a section of human colon containing a tumour. The strangest thing that Jamie has to come to terms with is the defamiliarising notion of the pathologist dissecting the tissue ('The pile of sliced colon mounting at the far edge of his board looked like chanterelle mushrooms, the fat squished under his fingers like cottage cheese. It might have been "nature", but there was nothing uplifting about it' $\left(S_{2} 8\right)$ ), and to then square this with the fact that the patient from whom it was removed is recovering in a ward upstairs. On a subsequent trip to the lab, Jamie observes sections of a liver tumour under the microscope: 'I was looking down from a great height upon a pink countryside, a landscape. There was an estuary, with a north bank and a south [. . . "It's like the Tay!" I said. "At low tide. With the sandbanks."' (S 30). This uncanny flip between the alien, cellular landscape of the fleshy 
material and the comparison with the homely is again familiar Jamie territory: to make the unknown somehow manageable, comprehensible, to partially domesticate the wild without usurping its innate magic. After observing a post-mortem, clearly her toughest challenge, for example, Jamie concludes the essay by leaving the hospital as visiting hour is commencing, feeling it was 'good to be part of that rough tribe of the mortal' ( $\left.S_{4} \mathrm{I}\right)$; the dramatic clash between the bustling hospital and the wildness of the earlier microscopic visions remaining all too apparent for the reader.

The Living Mountain, it seems, was too difficult a text to be assimilated into its age, not purely as a consequence of the economics of publishing, but also due to the impossibility of its very categorisation. ${ }^{14}$ Yet it is precisely this fusion of the exploration of the local, combined with philosophical rootedness in the body, and concomitant ontological quest, which have made this text so relevant for contemporary nature writers. While Shepherd's work lay hidden from view in a drawer for thirty years, her observations being too out of step with her contemporary world, for the contemporary 'new nature writers' this blending of the boundaries of travel and nature is de rigueur. While Shepherd is finely attuned to the possibilities of Being in The Living Mountain, Jamie is clearly writing from a more cluttered age, where the search for such purity of thought and solitary experience has inevitably become more challenging and difficult to negotiate. Yet, for Jamie, the mixture of mediating the natural world and the wild through the body, domesticating the wild in small, ordinary ways in order to make it at least partially comprehensible, can be regarded as central to her vision.

\section{WORKS Cited (SEE ALSO BIBLIOGRAPHy)}

Greig, Andrew, At the Loch of the Green Corrie (London: Quercus, 2010).

Macfarlane, Robert, 'I walk therefore I am', The Guardian (30 Aug 2008), http://www. theguardian.com/books/2008/aug/30/scienceandnature.travel (last accessed 24 May 2014).

McCulloch, Margery Palmer, Scottish Modernism and its Contexts 1918-1959: Literature, National Identity and Cultural Exchange (Edinburgh: Edinburgh University Press, 2009).

Muir, Edwin, Scottish Journey: A Modern Classic (Edinburgh: Mainstream Publishing, 1996). Shepherd, Nan, The Press and Journal (27 Oct 1977), NLS MS.27443.

Shepherd, Nan, 'The Living Mountain', The Grampian Quartet (Edinburgh: Canongate, I996).

Shepherd, Nan, The Living Mountain: a celebration of the Cairngorm Mountains of Scotland, introduced by Robert Macfarlane (Edinburgh: Canongate, 20I I).

\section{NOTES}

I. Nan Shepherd, The Living Mountain, p. 84 ( 1996 edition). Subsequent page references are to this edition.

2. Muir, Scottish Journey: A Modern Classic, p. IoI.

3. 'This divergence in priorities is true in the Scottish context as elsewhere. While the interwar cultural and political revival initiated by MacDiarmid was dominated by the aim to escape from a provincial North British identity and to achieve self-determination - politically in the longer term and more immediately through the rediscovery and renewal of distinctly 
Scottish forms of literary and artistic expression - for the women, especially as manifested in their writing, the search for self-determination in a gender sense came first. This does not mean that they were insensitive to or completely uninvolved in the national project.' McCulloch, Scottish Modernism, p. 70.

4. In the wider British context, for example, the mid-thirties saw the production of a series of travel books including Evelyn Waugh's Ninety-Two Days, Graham Greene's Journey without Maps and Orwell's The Road to Wigan Pier, as well as J. B. Priestley's English Journey.

Priestley's book was published the year before Edwin Muir's - these were companion books, commissioned by Heinemann and Gollancz.

5. Shepherd, The Press and Journal (1977).

6. Ibid.

7. Ibid., iii.

8. Greig, At the Loch of the Green Corrie, p. 94.

9. Macfarlane, 'I walk therefore I am'.

Io. Deborah Lilley also suggests that nature and the domestic are firmly entwined in Jamie's work: 'both the laundry and the birds are resolutely of the same world'. Lilley, 'Kathleen Jamie: Rethinking the Externality and Idealisation of Nature', in Green Letters, p. 22.

I I. Cowley, 'Editor's Letter: The New Nature Writing', p. Io.

I2. Ibid., pp. IO-I I.

I3. Dee, 'Nature Writing', p. 24.

I4. As Robert Macfarlane writes in his introduction to Shepherd's text: 'The Living Mountain is a formidably difficult book to describe. A celebratory prose-poem? A geo-poetic quest? A place-paean? A philosophical enquiry into the nature of knowledge? A metaphysical mashup of Presbyterianism and the Tao? None of these descriptions quite fits the whole, though it is all of these things in part.' (Shepherd, Living Mountain (201 I ), p. xiv) 